\title{
不斉エステル化反応によるキラルな非ステロイド性抗炎症剤（NSAIDs）の 新規供給法の開発
}

\author{
中田健也 也 $^{\dagger}$
}

\section{Development of Novel Methods for Preparing Chiral Non-Steroidal Anti-Inflammatory Drugs (NSAIDs) by Asymmetric Esterification}

\author{
Kenya Nakata ${ }^{\dagger}$ \\ Department of Applied Chemistry, Faculty of Science, Tokyo University of Science; \\ 1-3 Kagurazaka, Shinjuku-ku, Tokyo 162-8601, Japan.
}

(Received May 27, 2012)

\begin{abstract}
A novel and efficient method for preparing chiral 2-arylalkanoic acid derivatives, including non-steroidal anti-inflammatory drugs (NSAIDs) such as ibuprofen, ketoprofen, fenoprofen, flurbiprofen, and naproxen, and their esters by asymmetric esterification is presented in this paper. A variety of optically active carboxylic esters are produced by the kinetic resolution of racemic 2-arylalkanoic acids with achiral alcohols, using carboxylic anhydrides in the presence of chiral acyl-transfer catalysts. It was found that the combination of the modified benzotetramisole-type catalyst, $(S)-\beta$ Np-BTM, and a newly designed nucleophile, di ( $\alpha$-naphthyl) methanol, in the presence of a carboxylic anhydride, $p$ methoxybenzoic anhydride (PMBA) or pivalic anhydride $\left(\mathrm{Piv}_{2} \mathrm{O}\right)$, is most suitable for producing the corresponding chiral esters from 2-arylpropionic acid derivatives, with high enantiomeric excess under very mild reaction conditions. Using this new chiral acylation system, fairly broad substrate scope could be realized despite the multi-functional groups on the aromatic ring of the substrate. It was also revealed that ortho-substituted aromatic compounds, especially, 2,5disubstituted aromatic ones were the most suitable compounds for providing a high selectivity.
\end{abstract}

Key words — asymmetric esterification; kinetic resolution; tetramisole derivative; non-steroidal anti-inflammatory drug; mixed-anhydride method

\section{1. はじめに}

プロピオン酸系の非ステロイド性抗炎症剤 (NSAIDs; Non-Steroidal Anti-Inflammatory Drugs) として知られるアリールプロピオン酸誘導体は，医 薬品や市販薬を問わず広く汎用される薬剤の 1 つで あり，これまでに活発な開発がなされ数多くの有用 な治療薬が上市されている（Fig. 1)。また，最近 ではいくつかの NSAIDs にアルツハイマー病の抑 制作用や抗腫瘍活性があることが認められ，ますま すこの分野の研究は盛んに行われている.

NSAIDs はカルボキシル基の $\alpha$ 位に不斉中心を有

The author declares no conflict of interest.

東京理科大学理学部応用化学科（T162-8601 東京都新 宿区神楽坂 1-3)

現所属：†島根大学大学院総合理工学研究科物質化学領 域（T690-8504 島根県松江市西川津町 1060)

e-mail: nakata@ riko.shimane-u.ac.jp

本総説は, 平成 23 年度日本薬学会関東支部奨励賞の受

賞を記念して記述したものである.
するため鏡像異性体が存在し，その多くは片方の光 学異性体の夕が有効成分として働くことが知られて いるが，実際にはナプロキセンを除いてラセミ混合 物として市販されているのが現状である．他方の光 学異性体は無用であるのみならず，ラセミ体として 服用することで副作用が引き起こされたり，それ自 身が予期せぬ薬理活性を示すことが報告されてい

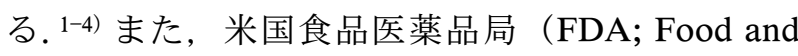
Drug Administration）が医薬品開発の際にラセミ 体として販売するならば不要な鏡像異性体が無害で あることを証明することを義務づけるラセミックス イッチの指針を通達するなど，以前から単一の異性 体の比率を増すことが求められている. したがつ て，当該分野の創薬研究を促すためにはそれぞれの エナンチオマーを作り分け, その特性を厳密に調査 する必要がある. ところで, 光学分割法はラセミ化 合物からその両エナンチオマーを誘導体として同時 に与える手法であるため，前述の目的に適つた有効 


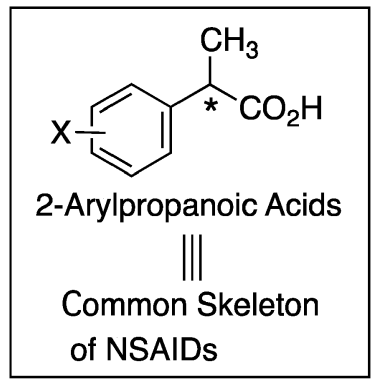<smiles>CC(C(=O)O)c1cccc(C(=O)c2ccccc2)c1</smiles><smiles>COc1ccc2cc(C(C)C(=O)O)ccc2c1</smiles>

Naproxen<smiles>CC(C(=O)O)c1cccc(Oc2ccccc2)c1</smiles>

Fenoprofen

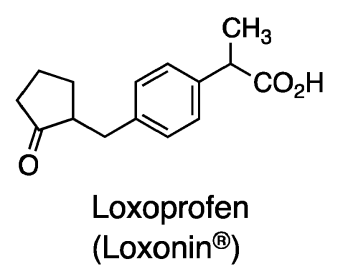

Fig. 1. Representative Example of NSAIDs

な手段となる. 従来から置換カルボン酸の光学分割 ではキラルなアミンを分割剤とするジアステレオ マー塩晶析法5)が実施されることが多いが，通常は カルボン酸の構造に適したアミンの同定や再結晶溶 媒の選択に時間を費やし煩雑な操作が必要とされ る. 酵素法ではルシフェラーゼの高い基質認識能を 利用したチオエステル化による効率的な光学分割 法6-8) も知られているが，この場合は基質特異性の 問題がある。また，合成化学的手法では光学活性な カルボン酸をラセミカルボン酸から直接与える有用 な方法はほとんど報告されていない。これらの社会 的要請及び学術的背景の下，筆者らは今回新たに光 学活性な NSAIDs の両鏡像異性体の簡便な供給法 を確立したのでその詳細について紹介するととも に，本稿においては，これを実現可能とした新しい 概念である不斉エステル化反応の開発の経緯につい ても解説する.

\section{2. 不斉エステル化反応の設計}

エステル化反応は基本的かつ重要な物質変換手段 の 1 つであるが, 効率よく, すなわち当量のカルボ ン酸とアルコールの脱水縮合により目的物を高収率 で与える優れた方法の選択肢は多くない。これに対 し, 筆者らの研究室では置換安息香酸無水物を反応 剂とするカルボン酸とアルコールの迅速カップリン グ反応を見い出し，これによりエステル並びにラク トンの簡便かつ実用的な合成プロセスを確立してい る (Scheme 1). 9-11) この反応では触媒としてアキラ ルな 4-dimethylaminopyridine（DMAP）を用いて いるため, ここで筆者らはアキラルな DMAP の代 わりに, なんらかのキラルな求核性触媒を適用する ことができれば本反応を不斉反応へと展開できるも
のと考えた.

計画する不斉エステル化反応ではキラルな触媒の 存在下で，系内で調製される混合酸無水物 (Mixed Anhydride; MA）を経由して反応が進行して光学 分割が行われるため, 同一の原理で求核剤並びに求 電子剂のいずれのラセミ化合物も分割可能であり, 対象を入れ替えることで適用できる基質が大幅に拡 張される利点がある（Scheme 2).

\section{3. ラセミアルコールの速度論的光学分割12-19)}

以上を踏まえ, 筆者らは入手容易なキラルな求核 性触媒として, 近年 Birman らによって不斉アシル 化反応において優れた触媒能を発揮することが明ら かとされたテトラミソール誘導体 ${ }^{20,21)}$ を選択し，こ れらを先述の置換安息香酸無水物法へと応用するこ とにした，不斉エステル化反応では原理的にラセミ カルボン酸及びラセミアルコールのいずれも取り扱 うことが可能だが, 目的のラセミカルボン酸の光学 分割は未知の課題であり困難が予想されたことか ら, 関連する研究として不斉アシル化反応による速 度論的光学分割が数多く報告されているラセミアル コールを基質として研究に着手し，まず，不斉エス テル化反応の実現を図ることにした.ここで詳細は 省略させて頂くが, 検討の結果, ベンゾテトラミ ソール (Benzotetramisole; BTM) 触媒の存在下で,

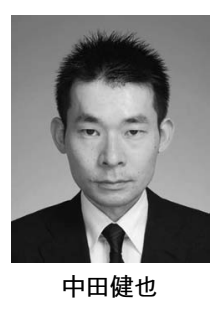

島根大学大学院総合理工学研究科・助 教. 2006 年東京工業大学大学院生命理 工学研究科博士課程修了, 博士 (工学) 取得, 2006 年東京理科大学博士研究 員, グリーン光科学技術センター研究 員, 2009 年東京理科大学理学部応用化 学科助教（椎名 勇教授）を経て，2012 年 1 月より現職. 専門: 有機化学. 


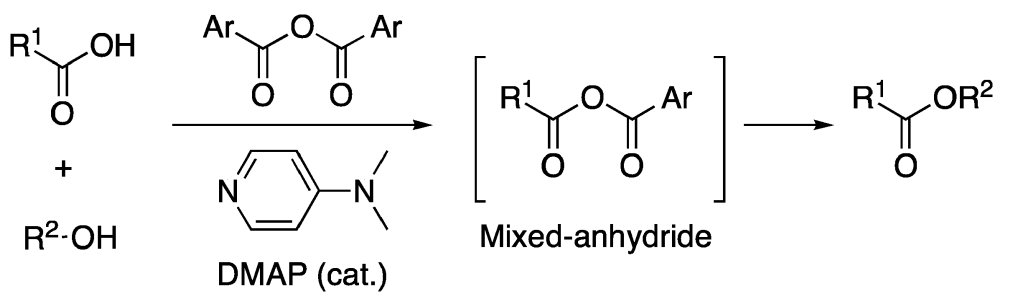

Scheme 1. Synthesis of Carboxylic Esters via the Mixed-anhydride (MA) Method

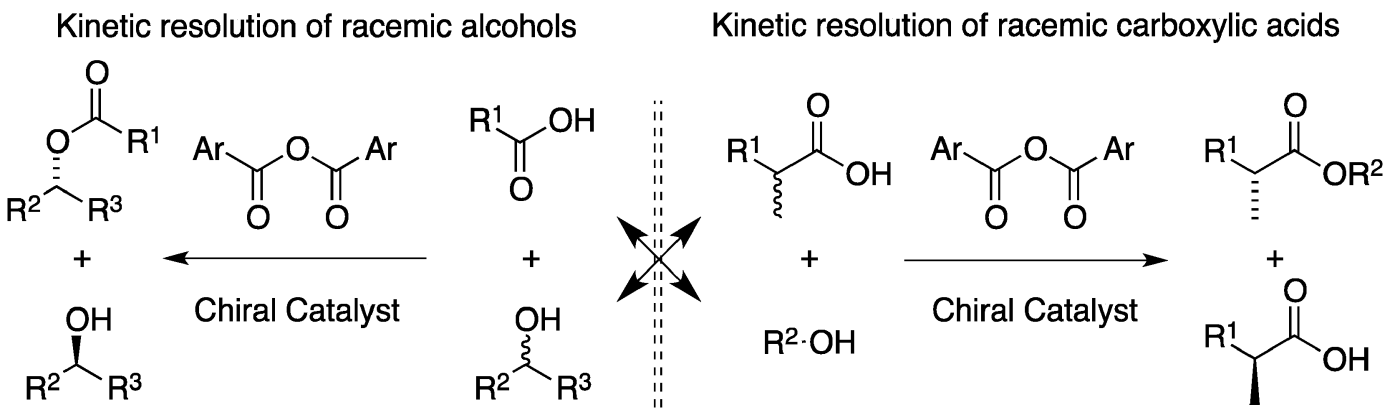

Scheme 2. Working Hypothesis of Asymmetric Esterification<smiles>CC[C@H](O)c1ccccc1</smiles>

$( \pm)-\mathbf{i}$

$$
\mathrm{CH}_{2}=\mathrm{CH}(\mathrm{CH})_{2} \mathrm{CO}_{2} \mathrm{H}(0.75 \text { eq.) }
$$

PMBA (0.90 eq.)

i- $\mathrm{Pr}_{2} \mathrm{NEt}(1.8 \mathrm{eq}$.)

$(R)$-BTM (5 mol\%)<smiles>C=CCCC(=O)OC(CC)c1ccccc1</smiles>

(R)-ii $47 \%$ yield $86 \%$ ee<smiles>CCC(O)c1ccccc1</smiles>

$(S)-\mathbf{i}$ $38 \%$ yield $91 \%$ ee<smiles>COc1ccc(C(=O)OC(=O)c2ccc(OC)cc2)cc1</smiles>

Scheme 3. KR of Racemic Alcohols by Asymmetric Esterification

縮合剂として安息香酸無水物 $\left(\mathrm{Bz}_{2} \mathrm{O}\right)$ 及び $p$-メト キシ安息香酸無水物（PMBA）が有効に機能する ことを見い出し, 2007 年, 遊離のカルボン酸をア シルドナーとする初の不斉エステル化反応によるラ セミ第 2 級アルコールの速度論的光学分割法 (Kinetic Resolution; KR）の開発に成功した（Scheme 3). ${ }^{12)}$

この反応では様々なカルボン酸が適用可能であ り，使用したアシルドナーに応じて対応する多彩な 光学活性なカルボン酸エステルとともにその逆の立 体化学を有する原料のアルコールをそれぞれ効率よ く与えることが判明した。 さらに，その選択性を評
価するために Kagan らによって提唱された $s$-值 ${ }^{22)}$ を算出したところ，おおむねその值が 20 を超える 良好な結果が得られた（なお，現在では $s$-值が 100 を超える条件が見い出されている)。15)

\section{4. ラセミカルボン酸の速度論的光学分割 $23-25)$}

4-1. 求核剤の設計前節で述べたように, 不 斉エステル化反応によるラセミアルコール類の速度 論的光学分割法を確立したので，ついで，対象基質 を置き換えて本題であるラセミカルボン酸の不斉エ ステル化反応の研究に取り組むことにした．先に見 い出した反応条件の下で，2-フェニルプロピオン酸 (土) -1 の速度論的光学分割をモデル反応として, 
求核剤として作用させるアキラルアルコールの構造 について精査することにした．詳細は原著論文で述 べた通りであるが，この反応における選択性は用い るアルコールの構造に大きく依存し，最終的な結果 として，ジ（ $\alpha$-ナフチル）メタノール（3）が最適 であることがわかった (Scheme 4).

4-2. 触媒の構造最適化 次に, 上記検討で求 まったアルコール 3 と PMBA を組み合わせた最良 の条件下で，触媒の構造最適化を試みた（Table 1)。一連の BTM 誘導体は対応するキラルなアミノ アルコールから容易に変換可能であり，調製した触 媒の置換基に関してその立体効果を評価したとこ ろ，この反応では不斉中心に直結した置換基がアル キル基よりもアリール基の方が適しており，優れた 新規縮合促進剂として $(S)-\alpha-\mathrm{Np}$-BTM と $(S)-\beta$-NpBTM を見い出すことができた（Entries 9 and 10).

\section{4-3. 光学活性ナプロキセンの両鏡像異性体の合} 成引き続き，先に良好な結果を与えた BTM,

$(S)-\alpha$-Np-BTM 及び $(S)-\beta$-Np-BTM を代表的な NSAIDs の 1 つである抗炎症剤ナプロキセン $( \pm)-4$ の速度論的光学分割に適用したところ，この場合も 反応はいずれも円滑に進行し高い選択性が得られ， そのうち $(S)$ - $\beta$-Np-BTM が最も効果的に働くことが 明らかとなった。なお，この反応条件下で原料の力 ルボン酸のラセミ化が起こっていることが判明し, 正確な $s$-值を求めることができなかったため，ここ では反応の終点の值のみから計算した $S_{\text {app }}$-值を用 いて選択性の評価を行った。また，縮合剤として PMBA の代わりにピバル酸無水物 $\left(\mathrm{Piv}_{2} \mathrm{O}\right)$ も利用 可能であることがわかった．生成したナプロキセン エステル（ $(S)$-5) はパラジウム触媒の存在下でそ の光学純度を損なうことなく容易に加水素分解され 対応する $(S)$-ナプロキセンへと変換することがで
き，その結果，これら一連の反応を通じてナプロキ センの両鏡像異性体を高エナンチ才選択的に得る手 法を確立することができた（Scheme 5).

4-4. キラルな NSAIDs の合成Ｔable 2 に示 すように，筆者らはこれまでの検討で明らかとした 最適の反応条件を用いて NSAIDsを含む様々なラ セミカルボン酸の速度論的光学分割を試みた。ま ず，基質の芳香環上の置換基の影響について体系的 に調査することにした，電子的効果を明らかとする ため誘起効果を有する電子供与性基並びに電子吸引 性基でパラ位が置換した基質を用いたところ，とも に良好な $S_{\text {app }}$-值を与えたが Entry 1 の無置換の構造 を基準にして比較するといずれも選択性が低下した (Entries 2 and 4). 一方, 共鳴効果により電子を供 与するメトキシ基を導入した場合は高い選択性が得 られた（Entry 3)。次に，立体的効果も考慮するた めに，オルト位に先と同一の置換基を有する基質を 同様の反応にそれぞれ附したところ，先程と類似し た電子的影響の傾向が観察され，これらの場合はよ り高い選択性で反応が進行することがわかった (Entries 5-7)。詳細な検討の結果，この反応ではオ ルト位に加えメ夕’ 位に置換を有するものが最も適 しており，特に Entry 8 の反応においては理想的に 光学分割が行われた $\left(s_{\mathrm{app}}=484\right)$. 引き続き, 様々 な NSAIDs の速度論的光学分割を実施したところ いずれも予想通り反応は効率よく進行し，この手法 は広範な基質一般性を有することを明らかとするこ とができた (Entries 9-12).

\section{5. 反応機構}

ラセミカルボン酸の速度論的光学分割では混合酸 無水物（MA）を経由する 2 度のトランスアシル化 を経由するため, 2 度の速度論的光学分割の可能性 が考えられた，そこで反応機構を考察する目的でま<smiles>CC(C(=O)O)c1ccccc1</smiles>

$( \pm)-1$
$(\alpha-\mathrm{Np})_{2} \mathrm{CHOH}(3)$ (0.75 eq.)

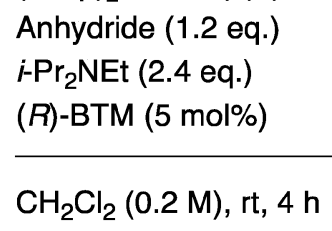

$\mathrm{CH}_{2} \mathrm{Cl}_{2}(0.2 \mathrm{M}), \mathrm{rt}, 4 \mathrm{~h}$

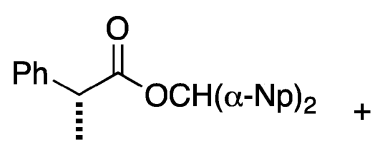

$(R)-2$<smiles>CC(C(=O)O)c1ccccc1</smiles>

(S)-1

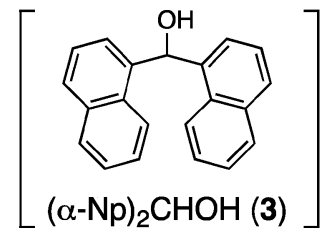

$\mathrm{Bz}_{2} \mathrm{O} ; \quad(R)-2 ; 56 \%, 81 \%$ ee, (S)-1; $19 \%, 80 \%$ ee

PMBA; (R)-2; 46\%, 86\% ee, (S)-1; $46 \%, 60 \%$ ee

Scheme 4. KR of $( \pm)-1$ Using $(\alpha-\mathrm{Np})_{2} \mathrm{CHOH}(3)$ 
Table 1. KR of $( \pm)-\mathbf{1}$ Using Various Catalysts<smiles>CC(C(=O)O)c1ccccc1</smiles>

$( \pm)-1$
$(\alpha-\mathrm{Np})_{2} \mathrm{CHOH}(3)$ (0.5 eq.)

PMBA (0.6 eq.)

$i-\mathrm{Pr}_{2} \mathrm{NEt}(0.9$ eq.)

Catalyst (5 mol\%)

$\mathrm{CH}_{2} \mathrm{Cl}_{2}(0.2 \mathrm{M}), \mathrm{rt}, 24 \mathrm{~h}$

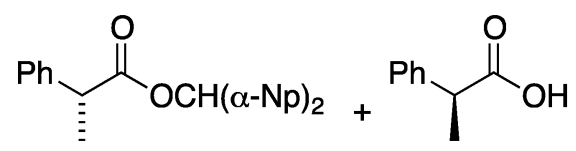

$(-)-(R)-2$

or

$(+)-(S)-2$
(+)-(S)-1

or

$(-)-(R)-1$

\begin{tabular}{|c|c|c|c|c|}
\hline Entry & Catalyst & & $\begin{array}{c}\text { Ester } 2 \\
\text { Yield }[\%] \quad(\% \text { ee })\end{array}$ & $\begin{array}{c}\text { Acid } 1 \\
\text { Yield [\%] (\% ee) }\end{array}$ \\
\hline 1 & & $(R)$-BTM & $33(-89 \%$ ee $)$ & $49(41 \%$ ee $)$ \\
\hline 2 & & $(S)$-BTM & $34(87 \%$ ee $)$ & $58(-38 \%$ ee $)$ \\
\hline 3 & & (S) $-i$-Pr-BTM & $42(64 \%$ ee $)$ & $35(-46 \%$ ee $)$ \\
\hline 4 & & $(S)$ - $t$-Bu-BTM & $6(-10 \%$ ee $)$ & $61(1 \%$ ee $)$ \\
\hline 5 & & (S) -Bn-BTM & $44(55 \%$ ee $)$ & $42(-42 \%$ ee $)$ \\
\hline 6 & & $(R)-\beta-\mathrm{NpCH}_{2}-\mathrm{BTM}$ & $44(-50 \%$ ee $)$ & $40(35 \%$ ee $)$ \\
\hline 7 & & $(R, R)$-noref-BTM & $22(12 \%$ ee $)$ & $52(-8 \%$ ee $)$ \\
\hline 8 & & $(R, S)$-fused-BTM & $23(-12 \%$ ee $)$ & $54(5 \%$ ee $)$ \\
\hline 9 & & $(S)-\alpha-\mathrm{Np}-\mathrm{BTM}$ & $29(88 \%$ ee $)$ & $67(-23 \%$ ee $)$ \\
\hline 10 & & $(S)$ - $\beta$-Np-BTM & $40(91 \%$ ee $)$ & $56(-44 \%$ ee $)$ \\
\hline
\end{tabular}

ず，第一のトランスアシル化の過程における原料の 鏡像異性体間での MA の形成の差を NMR 実験に より評価した（Scheme 6)。 それぞれ半量の $(S)$-1 と $(R)$-1 $\left(\mathrm{Me}^{\mathrm{d}} \mathrm{d}_{3}\right)$ を含む混合物を求核剂であるアキ ラルアルコールを添加せずに, 不斉エステル化反応 と同様の条件に附したところ，いずれも約 $40 \%$ が MA に変換され対応する $(S)$-1-MA と $(R)$-1-MA
$\left(\mathrm{Me}-\mathrm{d}_{3}\right)$ が $51: 49$ の比で発生していることがわか つた.

この結果より立体選択性はアキラルアルコールの 求核攻撃で発現し，混合酸無水物は系中で平衡的に 発生していることがわかった，すなわち， $(R)$ 1-MA とアキラルアルコールの反応により目的のエ ステル $(R)$-2 が生じ，一方で系内に残存する $(S)$ - 
<smiles>COc1ccc2cc(C(C)C(=O)O)ccc2c1</smiles>

naproxen (( \pm$)-4)$
$(\alpha-\mathrm{Np})_{2} \mathrm{CHOH}(3)(0.5$ eq. $)$ Anhydride (1.2 eq.)

$i-\mathrm{Pr}_{2} \mathrm{NEt}(1.8 \mathrm{eq}$.)

Catalyst (5 mol\%)

$\mathrm{CH}_{2} \mathrm{Cl}_{2}(0.1 \mathrm{M}), \mathrm{rt}, 12 \mathrm{~h}$

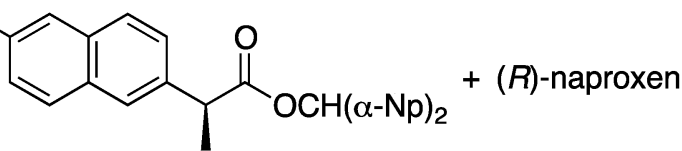

$(S)-5$

(S)-BTM, PMBA; (S)-5; 48\%, 76\% ee, $(R)-4 ; 40 \%, 59 \%$ ee, $s_{\text {app }}=13$ (S)- $\alpha$-Np-BTM, PMBA; (S)-5; 43\%, 88\% ee, (R)-4; 48\%, 44\% ee, $s_{\text {app }}=25$ (S)- $\beta$-Np-BTM, PMBA; (S)-5; 49\%, 93\% ee, $(R)-4 ; 51 \%, 74 \%$ ee, $s_{\text {app }}=61$ (S)- $\beta$-Np-BTM, Piv $_{2} \mathrm{O} ;(S)-5 ; 43 \%, 93 \%$ ee, $(R)-4 ; 37 \%, 69 \%$ ee, $s_{\text {app }}=59$<smiles>COc1ccc2cc(C(C)C(=O)OCC([N+]#N)[N+](=O)[O-])ccc2c1</smiles>

(S)-5; $93 \%$ ee

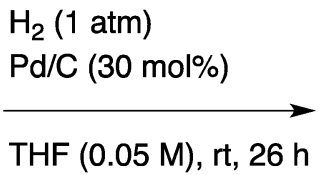

$85 \%$<smiles>COc1ccc2cc([C@@H](C)C(=O)O)ccc2c1</smiles>

(S)-naproxen; 93\% ee

Scheme 5. Production of $(S)$ and $(R)$-Naproxen (4)

Table 2. KR of a Variety of Racemic 2-Arylpropanoic Acids Including NSAIDs $(\alpha-\mathrm{Np})_{2} \mathrm{CHOH}(3)$ (0.5 eq.)<smiles>[Y][Y]1ccc([C@@H](C)C(=O)O)cc1</smiles>

$( \pm)-6$
$\mathrm{Piv}_{2} \mathrm{O}$ (1.2 eq.) $i-\mathrm{Pr}_{2} \mathrm{NEt}$ (1.8 eq.)

(S)- $\beta$-Np-BTM (5 mol\%)

$\mathrm{CH}_{2} \mathrm{Cl}_{2}(0.2 \mathrm{M}), \mathrm{rt}, 12 \mathrm{~h}$

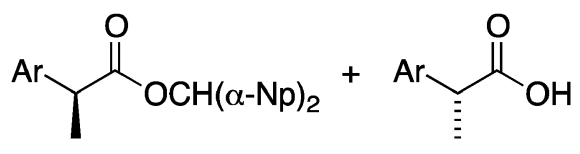

(S)-7
$(R)-6$

\begin{tabular}{rllccr}
\hline \hline \multirow{2}{*}{ Entry } & \multicolumn{1}{c}{ X, Y } & \multirow{2}{*}{ Acid } & $\begin{array}{c}\text { Ester 7 } \\
\text { Yield }[\%] \text { ee })\end{array}$ & $\begin{array}{c}\text { Acid } \mathbf{6} \\
\text { Yield }[\%] \text { ee })\end{array}$ & $S_{\text {app }}$ \\
\hline 1 & H, H & 6a $(=\mathbf{1})$ & $45(92)$ & $51(59)$ & 44 \\
2 & $4-\mathrm{Me}, \mathrm{H}$ & $\mathbf{6 b}$ & $48(86)$ & $39(62)$ & 26 \\
3 & $4-\mathrm{MeO}, \mathrm{H}$ & $\mathbf{6 c}$ & $50(89)$ & $33(77)$ & 41 \\
4 & $4-\mathrm{Cl}, \mathrm{H}$ & $\mathbf{6 d}$ & $49(82)$ & $34(68)$ & 20 \\
5 & $2-\mathrm{Me}, \mathrm{H}$ & $\mathbf{6 e}$ & $45(95)$ & $30(71)$ & 89 \\
6 & $2-\mathrm{MeO}, \mathrm{H}$ & $\mathbf{6 f}$ & $48(98)$ & $30(73)$ & 193 \\
7 & $2-\mathrm{Cl}, \mathrm{H}$ & $\mathbf{6 g}$ & $46(94)$ & $34(75)$ & 76 \\
8 & $2-\mathrm{Me}, 5-\mathrm{Me}$ & $\mathbf{6 h}$ & $40(98)$ & $43(99.5)$ & 484 \\
9 & $4-i-\mathrm{Bu}, \mathrm{H}$ & ibuprofen $(\mathbf{6 i})$ & $42(93)$ & $32(67)$ & 55 \\
10 & $3-\mathrm{Bz}, \mathrm{H}$ & ketoprofen $(\mathbf{6 j})$ & $48(85)$ & $48(62)$ & 23 \\
11 & $3-\mathrm{PhO}, \mathrm{H}$ & fenoprofen $(\mathbf{6 k})$ & $46(88)$ & $39(67)$ & 32 \\
12 & $3-\mathrm{F}, 4-\mathrm{Ph}$ & flurbiprofen $(\mathbf{6 l})$ & $46(87)$ & $42(67)$ & 29 \\
\hline
\end{tabular}

1-MA は反応の終了時に加水分解されカルボン酸 $(S)$-1 乞と変換されることでこれらがいずれも高工 ナンチオ選択的に得られたものと考えられる (Scheme 7).

6. おわりに

光学活性なカルボン酸をラセミカルボン酸から直 接与える有用な方法は，筆者らが本研究に着手した
2007 年当初報告されていなかった。これに対し, 筆者らは従来全く試みられていない研究領域である 脱水縮合反応に不斉触媒を組み合わせる手段の開発 を図り，新しい反応形式である不斉エステル化反応 を見い出し，これによりラセミカルボン酸の速度論 的光学分割による効率的な供給法を確立することが できた。本反応で得られる光学活性な 2 -アリール 


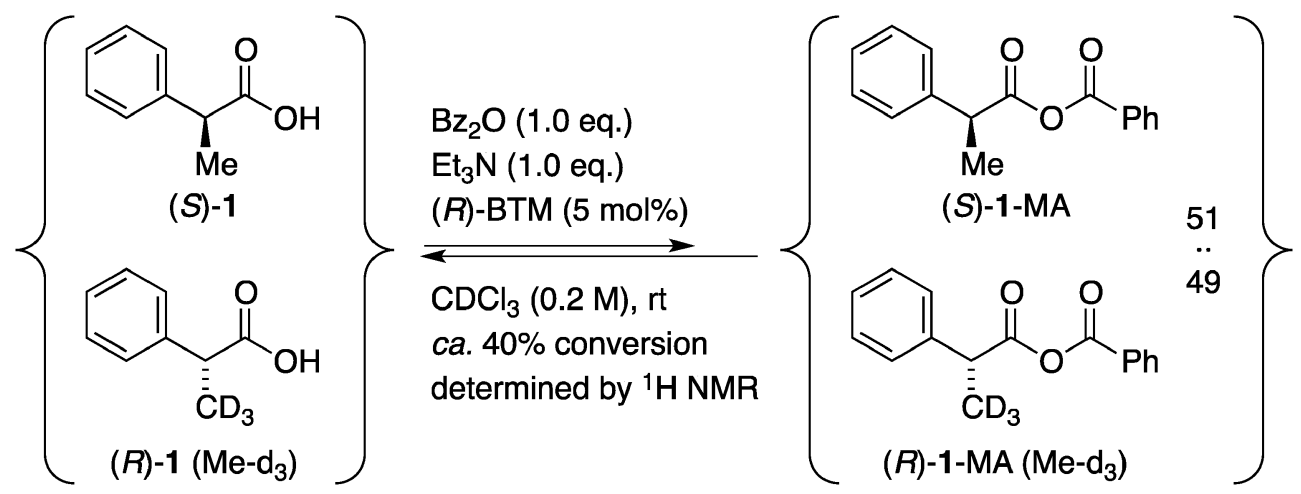

Scheme 6. Formation of a Mixture of Mixed Anhydrides

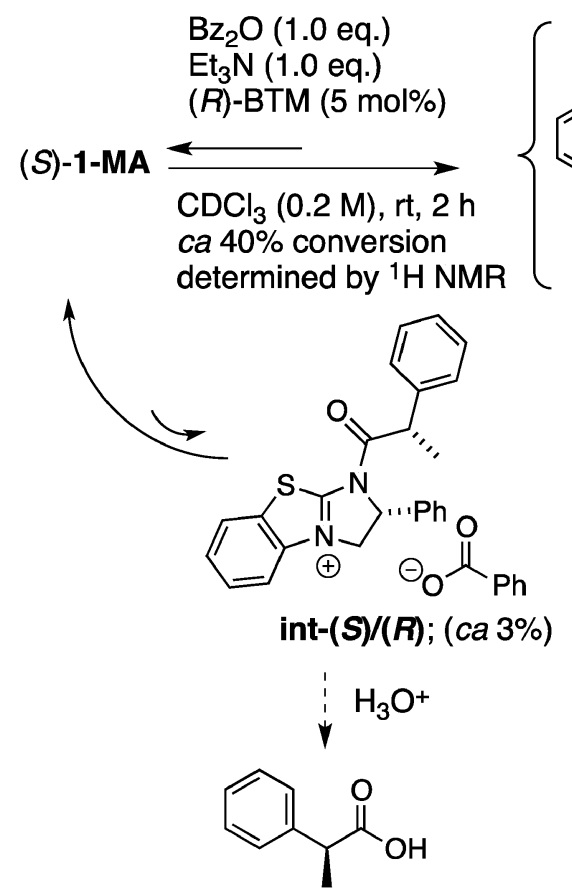

(S)-1

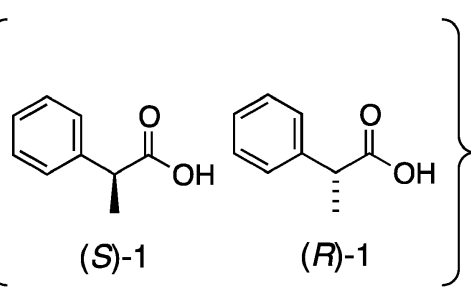

$\mathrm{Bz}_{2} \mathrm{O}$ (1.0 eq.)

$\mathrm{Et}_{3} \mathrm{~N}$ (1.0 eq.)

(R)-BTM (5 mol\%)

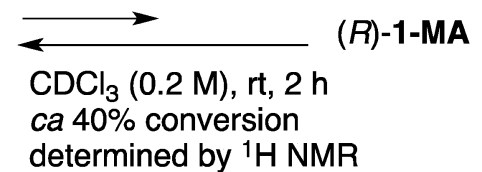

determined by ${ }^{1} \mathrm{H}$ NMR

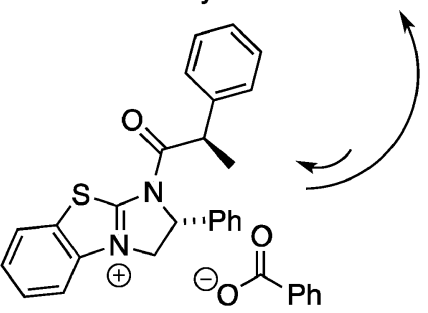

int- $(R) /(R)$; (ca 3\%)

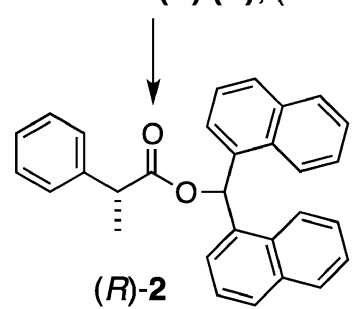

Scheme 7. Plausible Reaction Mechanism

プロピオン酸誘導体は非ステロイド性抗炎症剤 （NSAIDs）として汎用されており，この方法を活 用した新規薬剤の開発が期待される. 今後,この手 法を活用した新しい物質変換法の創出を目指してい きたいと考えている.

謝辞 本研究は, 筆者の東京理科大学理学部応 用化学科在任中の研究成果であり, 本研究を行うに あたり終始熱心なご指導，ご鞭撻を賜りました椎名 勇教授に厚くお礼申し上げます。また，本研究の遂 行にあたりともに実験に取り組んだ椎名研究室の学
生諸子に深く感謝いたします。さらに，これまで研 究室生活をともにしたすべての方々にこの場をかり て深謝いたします。

\section{REFERENCES}

1) Lee E. J. D., Williams K., Day R., Graham G., Champion D., J. Clin. Pharmacol., 19, 669-674 (1985) .

2) Williams K., Day R., Knihinicki R., Duffield A., Biochem. Pharmacol., 35, 3403-3405 (1986). 
3) Wechter W. J., Bigornia A. E., Murray E. D., Levine B. H., Young J. W., Chirality, 5, 492494 (1993).

4) Wetcher W. J., J. Clin. Pharmacol., 34, 10361042 (1994).

5) Harrington P. J., Lodewijk E., Org. Process Res. Dev., 1, 72-76 (1997).

6) Kato D., Teruya K., Yoshida H., Takeo M., Negoro S., Ohta H., FEBS J., 274, 3877-3885 (2007) .

7) Kato D., Yokoyama K., Hiraishi Y., Takeo M., Negoro S., Biosci. Biotechnol. Biochem., 75, 1758-1762 (2011).

8) Kato D., Tatsumi T., Bansho A., Teruya K., Yoshida H., Takeo M., Negoro S., J. Mol. Catal. B: Enzym., 69, 140-146 (2011).

9) Shiina I., Tetrahedron, 60, 1587-1599 (2004).

10) Shiina I., Kubota M., Oshiumi H., Hashizume M., J. Org. Chem., 69, 1822-1830 (2004).

11) Shiina I., Chem. Rev., 107, 239-273 (2007).

12) Shiina I., Nakata K., Tetrahedron Lett., 48, 8314-8317 (2007).

13) Shiina I., Nakata K., Sugimoto M., Onda Y., Iizumi T., Ono K., Heterocycles, 77, 801-810 (2009).

14) Nakata K., Shiina I., Heterocycles, 80, 169-
175 (2010).

15) Shiina I., Nakata I., Ono K., Sugimoto M., Sekiguchi A., Chem. Eur. J., 16, 167-172 (2010)

16) Shiina I., Ono K., Nakata K., Chem. Lett., 40, 147-149 (2011).

17) Nakata K., Ono K., Shiina I., Heterocycles, 82, 1171-1180 (2011).

18) Nakata K., Shiina I., Org. Biomol. Chem., 9, 7092-7096 (2011).

19) Nakata K., Sekiguchi A., Shiina I., Tetrahedron: Asymmetry, 22, 1610-1619 (2011).

20) Birman V. B., Li X., Org. Lett., 8, 1351-1354 (2006)

21) Ximin L., Jiang H., Uffman E. W., Guo L., Zhang Y., Yang X., Birman V. B., J. Org. Chem., 77, 1722-1737 (2012).

22) Kagan H. B., Fiaud J. C., Top. Stereochem. 18, 249-330 (1988).

23) Shiina I., Nakata K., Onda Y., Eur. J. Org. Chem., 5887-5890 (2008).

24) Shiina I., Nakata K., Ono K., Onda Y., Itagaki M., J. Am. Chem. Soc., 132, 1162911641 (2010)

25) Nakata K., Onda Y., Ono K., Shiina I., Tetrahedron Lett., 51, 5666-5669 (2011). 